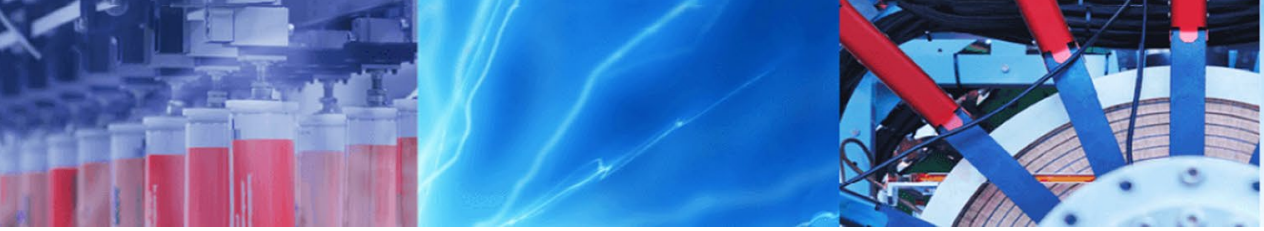

Research Article

\title{
Uptake and release of chromium and nickel by Vetiver grass (Chrysopogon zizanioides (L.) Roberty)
}

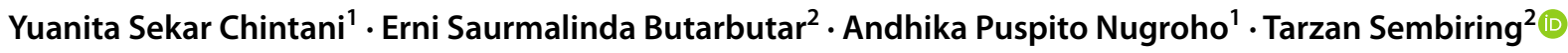

Received: 23 November 2020 / Accepted: 28 January 2021 / Published online: 6 February 2021

(C) The Author(s) 2021 OPEN

\begin{abstract}
The effectiveness of using Vetiver grass (Chrysopogon zizanioides) in phytoremediation of wastewater has been proven. In this study, the phytoremediation potential of $\mathrm{C}$. zizanioides planted in $\mathrm{Cr}$ - and $\mathrm{Ni}$-contaminated soil was evaluated through investigating the behaviors on uptake and release of metals. Three treatments: control, $\mathrm{Cr}$, and $\mathrm{Ni}$, with three concentrations (50,150, and $300 \mathrm{ppm}$ ), were applied. The potential of $C$. zizanioides is assessed by the determination of metal uptake rate, metal release rate, bioconcentration factor (BCF), biological absorption coefficient (BAC), and translocation factor (TF). The experiment showed that $\mathrm{Cr}$ uptake was higher than release rate and on the other hand low in uptake and release of $\mathrm{Ni}$. Accumulation of $\mathrm{Cr}$ and $\mathrm{Ni}$ was $167.8 \mathrm{mg} \mathrm{kg}^{-1}$ and $66.3 \mathrm{mg} \mathrm{kg}^{-1}$, respectively. Excess of $\mathrm{Cr}$ in the soil was absorbed in high uptake rate making vetiver grass suitable for $\mathrm{Cr}$ phytoremediation. During 28-day uptake and 28-day release periods, it was found that BCF, BAC, and TF values in some treatments showed greater than 1 (one) and Ni-treated plants were able to translocate $\mathrm{Ni}$ to aerial plant parts supported by its high TF value. Low acidity of soil causes low solubility and low mobility of metals, resulting in low metal absorption. C. zizanioides has shown the potential as a heavy metal-tolerant species and could be potentially used as phytoremediation alternative species at least in lightly polluted areas.
\end{abstract}

Keywords Bioconcentration · Chrysopogon zizanioides · Heavy metals · Phytoremediation · Plant uptake · Translocation

\section{Introduction}

Heavy metal in wastewater presents a critical threat to our environment. Mining and manufacturing industries, such as electroplating, contribute an immense quantity of heavy metals that pollute the air, soil, and groundwater $[10,18,22,29]$. Phytoremediation represents a promising method for heavy metal removal as it is accessible, costeffective, and environmentally friendly for remediation of contaminated areas [33]. Two of the strategies of phytoremediation are phytoextraction and phytostabilization. Phytoextraction utilizes the ability of uptake and accumulation of metals into plant shoots, while phytostabilization utilizes the plant's ability to minimize metal mobility in contaminated soils.

In ecotoxicology, it is necessary to establish the correlations between bioavailability of metals in the environment and tissues by using bioconcentration factors and the cause of biological effects that result from metal concentration in soft tissues. The means to establish these correlations are to achieve the ultimate aims: to predict and diagnose the cause-effect of exposure to heavy metals and environmental stress and the resultant ecological and biological effects [37]. In this study, the former was focused upon.

Tarzan Sembiring, sembiring_t@yahoo.com | ${ }^{1}$ Faculty of Biology, Universitas Gadjah Mada, Jl. Teknika Selatan, Sekip Utara, Sleman, Yogyakarta 55281, Indonesia. ${ }^{2}$ Research Unit for Clean Technology, Indonesian Institute of Sciences (LIPI), Jl. Sangkuriang, Bandung 40135, Indonesia. 
The use of vetiver grass (C. zizanioides) has been proven as an effective technique in phytoremediation. C. zizanioides is reported to be effective to absorb pollutants and nutrients, especially nitrogen $(\mathrm{N})$ and phosphate $(\mathrm{P})$ [9]. The studies conducted have also shown that $C$. zizanioides is highly tolerant to extreme soil conditions, has a long and complex rooting system, and is remarkably effective at absorbing organic and inorganic pollutants. C. zizanioides are also proven to be able to improve wastewater quality, such as biogas wastewater, palm oil wastewater, trichloroethylene (TCE) wastewater-contaminated soil, and batik liquid wastewater [33].

It is reported in several studies that C. zizanioides have a high tolerance to a broad range of heavy metals in soil. Previous studies also indicated cadmium (Cd) phytostabilization potential of $C$. zizanioides, which was found to have no significant $\mathrm{Cd}$ toxicity symptoms throughout the experiments, indicating high adaptability and tolerability of heavy metals [25]. Other than $\mathrm{Cd}$, heavy metals such as chromium ( $\mathrm{Cr}$ ) and nickel (Ni) also pose significant concerns. $\mathrm{Cr}$ is a nonessential metal that can be toxic even at low concentrations, while $\mathrm{Ni}$ is an essential metal that can be toxic at high concentrations [4]. Accumulation of $\mathrm{Cr}$ in plants could reduce plant growth, induce chlorosis, and induce degradation of carotenoid; therefore, it forms ROS [21]. Excess of $\mathrm{Ni}$ intake could inhibit other heavy metals uptake, causing deficit which consequently inhibit plant growth. Ni excess could also interfere with antioxidant enzymes function, such as SOD, CAT, glutathione peroxidase (GSH-Px), glutathione reductase (GR), peroxidase (POD), guaiacol peroxidase (GOPX), and ascorbate peroxidase (APX). As a result, the plant's ability to fight ROS is decreased [3]. C. zizanioides possess high threshold levels of heavy metal compared to most vascular plants. While the threshold levels in other plants are $0.02-0.20 \mathrm{mg} \mathrm{kg}^{-1}$ and $10-30 \mathrm{mg} \mathrm{kg}^{-1}$ for $\mathrm{Cr}$ and $\mathrm{Ni}$, respectively, the threshold levels for $C$. zizanioides are $5-18 \mathrm{mg} \mathrm{kg}^{-1}$ and $347 \mathrm{mg} \mathrm{kg}^{-1}$, respectively [20].

The present study investigates the phytoremediation potential of $C$. zizanioides in greenhouse experiments. $\mathrm{Cr}$ and $\mathrm{Ni}$ concentrations in plants and the associated soils were analyzed. Metal uptake rate, metal release rate, bioconcentration factor (BCF), biological absorption coefficient (BAC), and translocation factor (TF) were also determined.

\section{Materials and methods}

\subsection{Preparation and planting}

Experiments were conducted in a greenhouse at the Research Unit for Clean Technology, Indonesian Institute of Sciences (LIPI) Bandung, West Java, Indonesia, without climate control. Conditions were as follows: soil temperature of $28-35^{\circ} \mathrm{C}$, room temperature of $29-40{ }^{\circ} \mathrm{C}, 100 \%$ relative humidity, and soil pH of 6.8-7 (Table 1). Soil was amended with low doses of urea and NPK fertilizer (ratio of urea to NPK is 1:3) in plastic pots. Only a single tuft was grown in each pot. Plants were watered regularly to maintain soil moisture.

\subsection{Experimental design}

A randomized complete block design with three replications and three treatments: control, $\mathrm{Cr}$, and $\mathrm{Ni}$, were used. Concentrations used for $\mathrm{Cr}$ and $\mathrm{Ni}$ treatments were $50 \mathrm{ppm}, 150 \mathrm{ppm}$, and $300 \mathrm{ppm}$. Non-contaminated soil is used as control.

Preparation of $1000 \mathrm{ppm} \mathrm{Cr}$ and $\mathrm{Ni}$ stock solution was done by dissolving $5.66 \mathrm{~g} \mathrm{~K}_{2} \mathrm{Cr}_{2} \mathrm{O}_{7}$ (EMSURE ${ }^{\oplus}$ ) and $4.48 \mathrm{~g}$ $\mathrm{NiSO}_{4} \cdot 6 \mathrm{H}_{2} \mathrm{O}\left(\mathrm{EMSURE}^{\oplus}\right)$ each in $1000 \mathrm{~mL}$ deionized water. Preparation of $50 \mathrm{ppm}, 150 \mathrm{ppm}$, and $300 \mathrm{ppm}$ metal solutions was carried out by diluting $50 \mathrm{~mL}, 150 \mathrm{~mL}$, and $300 \mathrm{~mL}$ of the stock solution into a $1000-\mathrm{mL}$ volumetric flask each and filled with deionized water.

Treatment was carried out by pouring the solution onto the soil, marking the day as the beginning of the phytoremediation process. The plants were grown for 28 days to absorb the heavy metals (known as metal uptake period); then, the remaining plants were transferred
Table 1 Environmental condition during uptake and release period weekly

\begin{tabular}{|c|c|c|c|c|c|c|c|c|}
\hline \multirow[t]{3}{*}{ Parameter } & \multicolumn{8}{|c|}{ Week } \\
\hline & \multicolumn{4}{|c|}{ Uptake } & \multicolumn{4}{|c|}{ Release } \\
\hline & 1 & 2 & 3 & 4 & 1 & 2 & 3 & 4 \\
\hline Soil temperature $\left({ }^{\circ} \mathrm{C}\right)$ & 32 & 35 & 29 & 30 & 28.5 & 29 & 28 & 29 \\
\hline Room temperature $\left({ }^{\circ} \mathrm{C}\right)$ & 37 & 32 & 31 & 34 & 40 & 41 & 29 & 40 \\
\hline Soil humidity (\%) & 100 & 100 & 100 & 100 & 100 & 100 & 100 & 100 \\
\hline Room humidity (\%) & 49 & 67 & 71 & 64 & 48 & 48 & 74 & 49 \\
\hline Soil pH & 6.8 & 7 & 7 & 7 & 7 & 7 & 7 & 7 \\
\hline
\end{tabular}


to non-contaminated soil and grown for 28 more days (known as metal release period).

\subsection{Sampling of soil, leaves, and roots}

Soil sampling was conducted at days 0 and 28 during uptake and release period. Five grams of soil was sampled from each pot and then dried until attaining a constant weight at low temperature $\left(50^{\circ} \mathrm{C}\right)$. Later, the samples were then digested using the wet acid digestion method [36]. $\mathrm{Cr}$ and $\mathrm{Ni}$ concentration were determined using atomic absorption spectrophotometer (AAS).

Two (2) grams of leaves was sampled from each treatment at days $0,4,14$, and 28 during the uptake and release period. Leaves were dried in an oven at low temperature $\left(50^{\circ} \mathrm{C}\right)$ until they attained a constant weight. The samples were then digested until the brownish color fade [24].

Root sampling was conducted on day 28 during the uptake and release period. The roots were thoroughly rinsed with tap water and dried until attaining a constant weight at low temperature $\left(50^{\circ} \mathrm{C}\right)$. Dry weight biomass of the roots was measured separately for each treatment. The dried roots then digested for analysis. In addition, the elemental content of the root on day 0 of uptake period was observed using SEM-EDS. Root samples used for SEM-EDS were dried at $50^{\circ} \mathrm{C}$ for $10-15 \mathrm{~min}$ and then cut into crosssectional samples in liquid nitrogen, which then plated with gold plating for the analysis process.

\subsection{Digestion process and determination of $\mathrm{Cr}$ and Ni concentration}

Soil digestion was carried out using the wet acid digestion method based on [36]. One (1) gram of dried soil was added with $12 \mathrm{~mL}$ of $\mathrm{HNO}_{3}\left(\right.$ EMSURE$\left.^{\oplus}\right)$ and $4 \mathrm{~mL}$ of $\mathrm{HCl}\left(\mathrm{EMSURE}^{\circledR}\right)$. The mixture was heated with a hot plate $\left(100^{\circ} \mathrm{C}\right)$ for $2 \mathrm{~h}$. The mixture was then moved into a 100$\mathrm{mL}$ volumetric flask, filtered with $0.45-\mu \mathrm{m}$ filter paper, and diluted with deionized water.

Leaves and roots were digested using the wet digestion method based on Pequerul et al. [24] with modification. Dry samples were crushed; then, $0.1 \mathrm{~g}$ of the sample was added with $1 \mathrm{~mL}$ of $65 \% \mathrm{HNO}_{3}$ (EMSURE ${ }^{\circledR}$ ) and shaken until the sample was wet. $0.8 \mathrm{~mL}$ of $33 \% \mathrm{H}_{2} \mathrm{O}_{2}$ (EMSURE ${ }^{\circledR}$ ) were slowly added to the solution and then homogenized. The sample was then heated with a hotplate at $100^{\circ} \mathrm{C}$ until bubbly. After the brownish color faded in 7-8 $\mathrm{min}$, the solution was cooled. It was then put into a $25-\mathrm{mL}$ volumetric flask, filtered with 0.45 - $\mu \mathrm{m}$ filter paper, added with $1 \mathrm{~mL}$ of $37 \% \mathrm{HCl}(1: 1)\left(\mathrm{EMSURE}^{\oplus}\right)$, and then diluted with deionized water.

Total contents of $\mathrm{Cr}$ and $\mathrm{Ni}$ were determined using Atomic Absorption Spectrophotometer (AAS) Agilent
Technologies 200 Series AA. The results obtained were converted from $\mathrm{mg} \mathrm{L}^{-1}$ to $\mathrm{mg} \mathrm{kg}^{-1}$. The unit conversion was based on Loney [13]. To avoid possible contamination, all glassware and equipments used were acid-washed.

$\frac{\mathrm{mg}}{\mathrm{kg}}=\left(\frac{\left[\text { concentration }\left(\frac{\mathrm{mg}}{\mathrm{L}}\right)\right]-\text { sample volume }(\mathrm{L})}{\text { dry weight of sample }(\mathrm{g})}\right) \times 1000$

\subsection{Data analysis}

The collected data were calculated to obtain the value of bioconcentration factor (BCF) as the ratio of heavy metal concentration in the roots to the soil, biological absorption coefficient (BAC) as the ratio of heavy metal concentration in leaves to the soil, translocation factor (TF) as the ratio of heavy metal concentration in leaves to root, metal uptake rate, and metal release rate $[11,15,37,38]$.

Statistical analysis of the collected data related to the concentration of $\mathrm{Cr}$ and $\mathrm{Ni}$ from uptake and release period in plant parts (leaves and roots) was performed using IBM-SPSS version 20.0 (SPSS 2006). Data are analyzed using the independent sample $t$ test (significance level of $p<0.05$ ) and the Mann-Whitney $U$ test (significance level of $p<0.05)$.

$\mathrm{BCF}=\frac{[\text { heavy metal }]_{\text {root }}}{[\text { heavy metal }]_{\text {soil }}} \quad \mathrm{BAC}=\frac{[\text { heavy metal }]_{\text {leaf }}}{[\text { heavy metal }]_{\text {soil }}}$

$\mathrm{TF}=\frac{[\text { heavy metal }]_{\text {leaf }}}{[\text { heavy metal }]_{\text {root }}}$

Metal uptake rate $=\frac{[\text { heavy metal }]_{\text {exposed }}-[\text { heavy metal }]_{\text {control }}}{\operatorname{Day}(s) \text { of metal exposure }}$

Metal release rate

$=\frac{[\text { heavy metal }]_{\text {end of metal exposure }}-[\text { heavy metal }]_{\text {end of metal release }}}{\text { Day }(s) \text { of metal exposure }}$

\section{Results and discussion}

\section{1 $\mathrm{Cr}$ and $\mathrm{Ni}$ concentration in soil}

$\mathrm{Cr}$ and $\mathrm{Ni}$ concentration in soil is assessed to evaluate the bioavailability of $\mathrm{Cr}$ and $\mathrm{Ni}$ in soil (Table 2). The results obtained showed a decrease of $\mathrm{Cr}$ and $\mathrm{Ni}$ content in soil at uptake period for plants treated with 
Table $2 \mathrm{Cr}$ and $\mathrm{Ni}$ concentration in each soil treatment on days 0 and 28 $\left(\mathrm{mg} \mathrm{kg}^{-1}\right)$

\begin{tabular}{|c|c|c|c|c|c|c|c|c|}
\hline \multirow[t]{3}{*}{ Treatment } & \multicolumn{4}{|l|}{$\mathrm{Cr}$} & \multicolumn{4}{|l|}{$\mathrm{Ni}$} \\
\hline & \multicolumn{2}{|l|}{ Uptake } & \multicolumn{2}{|c|}{ Release } & \multicolumn{2}{|c|}{ Uptake } & \multicolumn{2}{|c|}{ Release } \\
\hline & 0 & 28 & 0 & 28 & 0 & 28 & 0 & 28 \\
\hline Control & 17.46 & 0.00 & 0.00 & 3.84 & 12.05 & 4.61 & 0.00 & 8.55 \\
\hline 50 ppm & 63.86 & 28.14 & 0.00 & 4.92 & 37.35 & 35.98 & 0.00 & 23.05 \\
\hline 150 ppm & 122.97 & 92.73 & 0.00 & 6.53 & 82.05 & 156.37 & 0.00 & 7.95 \\
\hline 300 ppm & 70.94 & 209.50 & 0.00 & 5.21 & 19.29 & 257.94 & 0.00 & 10.70 \\
\hline
\end{tabular}

50 ppm Cr, 150 ppm Cr, and 50 ppm Ni. Heavy metal content in soil decreased from 63.9 to $28.1 \mathrm{mg} \mathrm{kg}^{-1}$ (by $55.9 \%$ ), 123.0 to $92.7 \mathrm{mg} \mathrm{kg}^{-1}$ (by $24.6 \%$ ), and 37.4 to $36.0 \mathrm{mg} \mathrm{kg}^{-1}$ (by 3.7\%), respectively. However, plants treated with 300 ppm Cr, 150 ppm Ni, and 300 ppm $\mathrm{Ni}$ showed an increase of $\mathrm{Cr}$ and $\mathrm{Ni}$ concentrations in its soil content varying from 70.9 to $209.5 \mathrm{mg} \mathrm{kg}^{-1}$ (by $66.1 \%$ ), 82.1 to $156.4 \mathrm{mg} \mathrm{kg}^{-1}$ (by $47.5 \%$ ), and 19.3 to $257.9 \mathrm{mg} \mathrm{kg}^{-1}$ (by 92.5\%), respectively. $\mathrm{Cr}$ and $\mathrm{Ni}$ accumulated in the treated soil were higher than that of the control soil. $\mathrm{Cr}$ concentration in soil of plants treated with 150 ppm and 300 is above the normal concentration range (12-44 $\mathrm{mg} \mathrm{kg}^{-1}$ ) and is within the range of the critical concentration (75-100 $\mathrm{mg} \mathrm{kg}^{-1}$ ), meaning that plants are in a $\mathrm{Cr}$-induced stress condition [26]. The same plants were treated with 150 ppm and 300 ppm $\mathrm{Ni}$, which also contained $\mathrm{Ni}$ higher than the normal concentration range (1-20 $\left.\mathrm{mg} \mathrm{kg}^{-1}\right)$ but within the critical range (100 $\mathrm{mg} \mathrm{kg}^{-1}$ ). This means that plants treated with 150 ppm and 300 ppm Ni are in a Ni-induced stress condition [26]. Even though plants were under $\mathrm{Cr}$ and $\mathrm{Ni}$ stress, several studies reported that $C$. zizanioides could survive under the highest levels of contaminants reported in the literature, which are $2290 \mathrm{mg} \mathrm{kg}^{-1}$ and $100 \mathrm{mg} \mathrm{kg}^{-1}$, respectively, for $\mathrm{Cr}$ and $\mathrm{Ni}$ [5].

The remaining plants were then transplanted to noncontaminated soil (metal release period). The results showed that the initial $\mathrm{Cr}$ and $\mathrm{Ni}$ concentration in all treatments was $0.0 \mathrm{mg} \mathrm{kg}^{-1}$. After 28 days of observation, the results showed an increase in all treatments varying from $4.9 \mathrm{mg} \mathrm{kg}^{-1}, 6.5 \mathrm{mg} \mathrm{kg}^{-1}$, and $5.2 \mathrm{mg} \mathrm{kg}^{-1}$, respectively, for $\mathrm{Cr}$ and $23.1 \mathrm{mg} \mathrm{kg}^{-1}, 8.0 \mathrm{mg} \mathrm{kg}^{-1}$, and $10.7 \mathrm{mg} \mathrm{kg}^{-1}$, respectively, for $\mathrm{Ni}$. $\mathrm{Cr}$ and $\mathrm{Ni}$ concentrations in treated soil are similar to non-contaminated soil and are within the range of published values [26].

These results indicate that $C$. zizanioides exhibited the ability to reduce $\mathrm{Cr}$ concentration in soil through a high absorption process, especially for 50 ppm and 150 ppm treatment. On the other hand, the ability to release $\mathrm{Cr}$ is relatively low. In addition, plants treated with $\mathrm{Ni}$ showed a relatively low absorption process for 50 ppm treatment, and $\mathrm{Ni}$ released by plants in all treatments was relatively low. C. zizanioides treated with 300 ppm Cr, 150 ppm Ni, and 300 ppm Ni were not able to absorb excess $\mathrm{Cr}$ and $\mathrm{Ni}$ in the soil as indicated by the increasing heavy metal concentration in soil at the end of the uptake period.

Theoretically, $\mathrm{Cr}$ and $\mathrm{Ni}$ concentration in soil in this study could reach up to $2500 \mathrm{mg} \mathrm{kg}^{-1}, 7500 \mathrm{mg} \mathrm{kg}^{-1}$, and $15,000 \mathrm{mg} \mathrm{kg}^{-1}$ for 50,150 , and 300 ppm, respectively. This turned out to be inconsistent with the results obtained on day 0 (beginning of metal uptake period), where the results obtained showed much lower metal concentration. One of the factors that affected the availability of heavy metal in the soil is acidity. Acid soils tend to make metals more soluble and mobile [12]. Soil pH in this study ranged between 6.8 and 7.0, thus making it a neutral soil (Table 1). Because of low acidity, this type of soil has low solubility and mobility of heavy metals, causing uneven distribution of heavy metals so the obtained concentration has not represented the real concentration.

Chrysopogon zizanioides root on day 0 of uptake condition (Fig. 1) reported to have high quantities of $\mathrm{C}$ and $\mathrm{O}$, which was $56.5 \%$ and $41.0 \%$, respectively, and low amount of $\mathrm{K} 1.1 \%$. The concentration of $\mathrm{Ni}, \mathrm{Mg}, \mathrm{Al}, \mathrm{P}, \mathrm{S}$, and $\mathrm{Cl}$ recorded was $0.3 \%, 0.1 \%, 0.04 \%, 0.3 \%, 0.3 \%$, and $0.5 \%$, respectively. The element distribution in the roots is reported to be evenly distributed as shown in Fig. 2. Analysis of SEM-EDS is acted as a preliminary analysis to detect whether $\mathrm{Ni}$ and $\mathrm{Cr}$ were observed in the root samples or not. From the result, it is reported that there were only $\mathrm{Ni}$ detected and no $\mathrm{Cr}$ in the roots. The presence of $\mathrm{Ni}$ indicates that $\mathrm{Ni}$ is an essential heavy metal for plants [3], and the absence of $\mathrm{Cr}$ is beneficial for the experiments as it would not affect the result of $\mathrm{Cr}$ accumulation in plant parts.

\subsection{Accumulation of $\mathrm{Cr}$ in leaves}

Figure 3a shows the total accumulation of $\mathrm{Cr}$ in leaves throughout the experiments. Overall, $\mathrm{Cr}$ concentration showed an increase throughout the uptake period. The highest $\mathrm{Cr}$ concentration is contained by leaves on day 14 . Compared to control plants, treated plants tend to have higher $\mathrm{Cr}$ concentrations, indicating that $\mathrm{Cr}$ excess in soil 

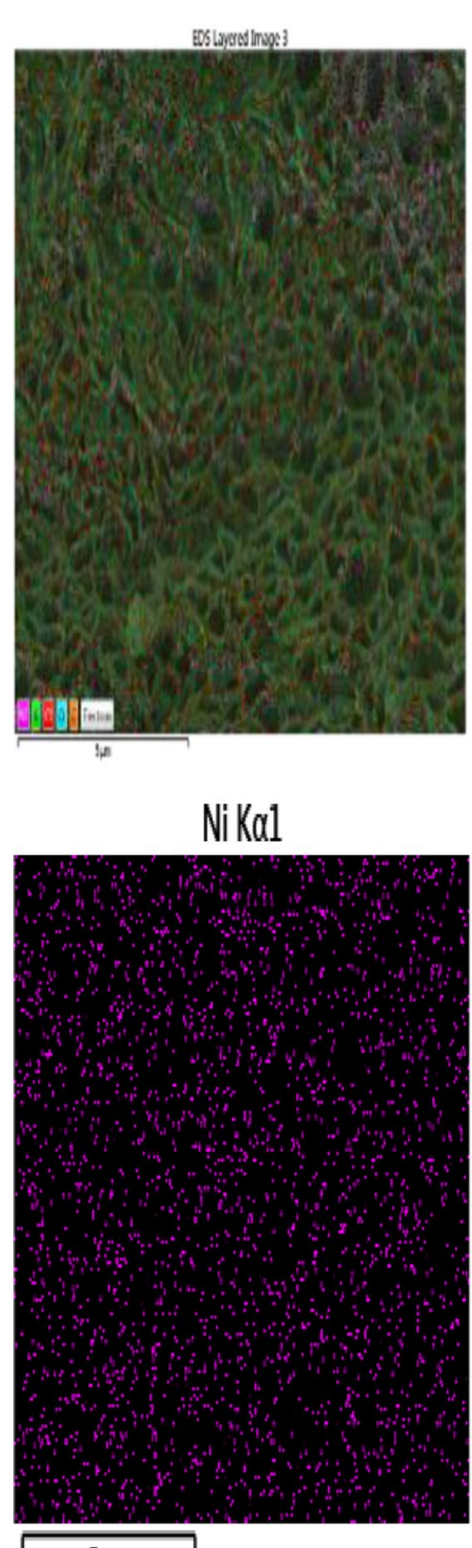

$5 \mu \mathrm{m}$
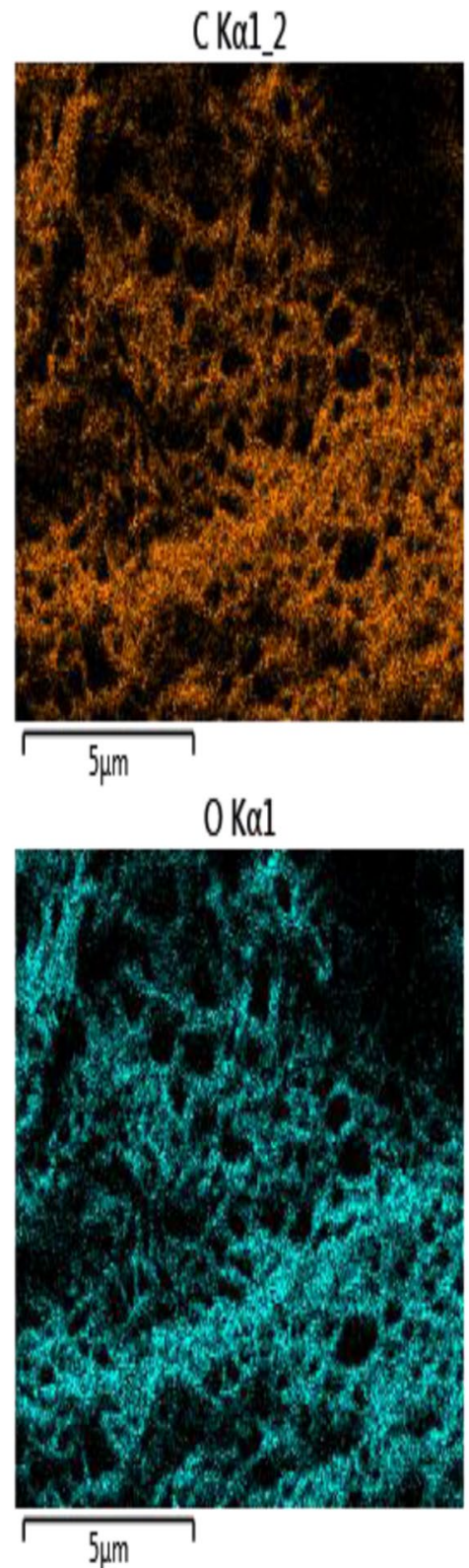
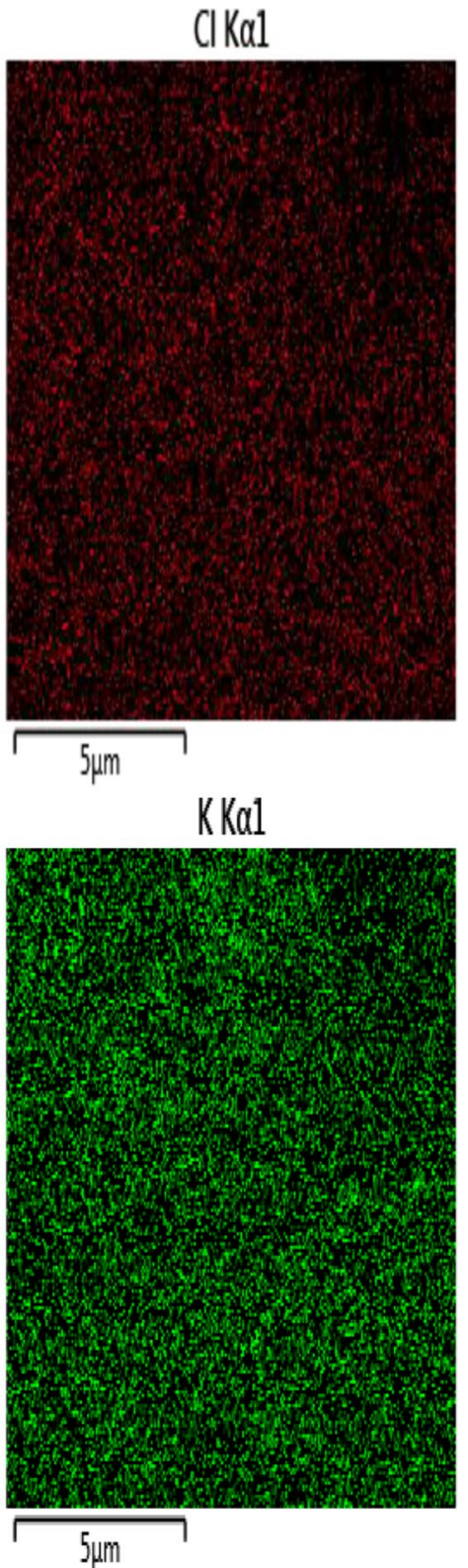

Fig. 1 Mapping of the elemental content distribution in C. zizanioides roots on day 0 of metal uptake period

is gradually absorbed and translocated to aerial plant parts. Cr concentration in plants treated with $150 \mathrm{ppm}$ and 300 ppm experienced a significant decrease on day 28. This may be due to excessive $\mathrm{Cr}$ accumulation by plants, causing metal saturation which then inhibits $\mathrm{Cr}$ absorption [19]. Several studies showed that $C$. zizanioides is the most Cr-tolerant plant among 36 plant species, regardless of $\mathrm{Cr}$ forms and rates. The plants can accumulate very high concentration of $\mathrm{Cr}$ varying from 404 to $1750 \mathrm{mg} \mathrm{kg}^{-1}$ for $\mathrm{Cr}$ (III) and up to $10,000 \mathrm{mg} \mathrm{kg}^{-1}$ in the shoots but died a few days later after exposure of $\mathrm{Cr}(\mathrm{VI})$ at a concentration of $500 \mathrm{mg} \mathrm{kg}^{-1}$ in the soil $[28,35]$.
After the plants were transplanted into non-contaminated soil, $\mathrm{Cr}$ concentration in each treatment tended to decrease and reached the lowest concentration on day 28 (Fig. 3b). Control plants had a very low $\mathrm{Cr}$ concentration when compared to treated plants. This tendency of decreasing concentration may be due to the extracted part that is the young leaves. Ordinarily, $\mathrm{Cr}$ accumulation occurs in the roots, which are then translocated into stems and leaves. In leaves, $\mathrm{Cr}$ is largely accumulated in the mature leaves rather than the young ones, which will be shed to reduce the metal that is absorbed by plants. 
Fig. 2 EDS peaks of elements in C. zizanioides roots on day 0 of metal uptake period

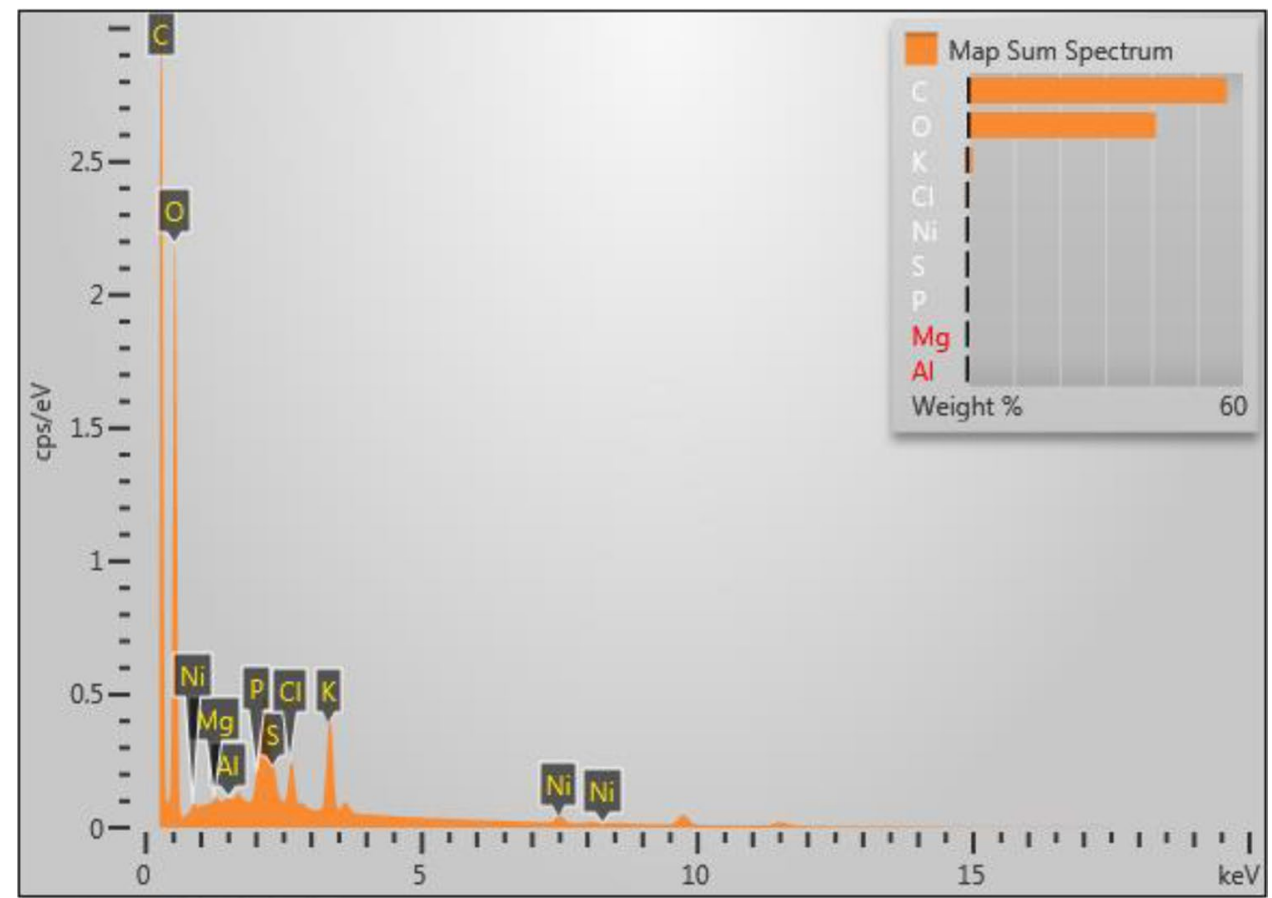

This is one of the plant strategies to reduce metal concentration in their bodies [19].

On day 4, $\mathrm{Cr}$ concentration has increased in $150 \mathrm{ppm}$ and 300 ppm treatment (Fig. 3a). This may be caused by the ability of plants to carry out a detoxification mechanism through the synthesis of phytochelatins. As a result, plants can survive, accumulate metals, then store them in their vacuoles, hence increasing the absorption ability [23]. On the other hand, Singh et al. [30] stated that stress due to $\mathrm{Cr}$ can reduce plant biomass. This was proved by the results exhibiting an increase in leaf biomass after 28 days of exposure to heavy metals.

\subsection{Accumulation of $\mathrm{Ni}$ in leaves}

$\mathrm{Ni}$ accumulation in leaves is shown in Fig. 4a. Obtained results exhibited an increase in $\mathrm{Ni}$ concentration throughout the uptake period. Plants treated with 50 ppm and 300 ppm were reported to accumulate the highest concentration on the last day of this period. This indicates that exposure duration affects the accumulated concentration of $\mathrm{Ni}$ in the leaves. In 150 ppm treatment, $\mathrm{Ni}$ reached the highest concentration at day 14, which was $25.1 \mathrm{mg} \mathrm{kg}^{-1}$. Ni concentration in control plants was relatively low compared to that of treated plants. The decreasing Ni concentration in plants treated with 150 ppm at day 28 may be due to excessive accumulation of Ni by plants, causing metal saturation which then inhibits the absorption of these metals [19]. Studies conducted by Truong [35] reported a high Ni accumulation in shoots (448 $\mathrm{mg} \mathrm{kg}^{-1}$ ), which, when compared to the recent findings, showed a huge difference, meaning that C. zizanioides is able to accumulate higher Ni concentrations than the results of this experiment.

Accumulation of $\mathrm{Ni}$ showed a decrease over the time at release period. Plants treated with 50 ppm and 150 ppm had the lowest concentration on day 28 , which was $6.2 \mathrm{mg} \mathrm{kg}^{-1}$ and $6.4 \mathrm{mg} \mathrm{kg}^{-1}$, respectively. The treatment using 300 ppm metal contains a lower concentration of $\mathrm{Ni}$ at day 14 , which was $14.4 \mathrm{mg} \mathrm{kg}^{-1}$. The control plants tended to have a very low concentration of $\mathrm{Ni}$ when compared to treated plants.

It is possible that the reduction of the Ni concentration in leaves was due to the extraction of plant samples. Samples used in the experiments were young leaves, which may contain a lesser concentration of Ni. Several studies showed that plants accumulate high quantities of heavy metals in plant roots. Heavy metals were then translocated from roots to leaves, favoring the mature leaves that will be shed later. This is one of the plant strategies used to excrete metals accumulated in its body [3]. Chen et al. [3] also stated that stress due to exposure to $\mathrm{Ni}$ can reduce the total dry weight accumulation in roots and stems, as well as the total plant biomass. This is due to poor plant development and reduced supply of nutrients to the reproductive parts of the plant. The statement was supported by the results obtained, which showed a decrease in biomass produced by the plants after 28 days at the uptake period. 
Fig. $3 \mathrm{Cr}$ concentration in leaves $\left(\mathrm{mg} \mathrm{kg}^{-1}\right)$ a metal uptake condition and $\mathbf{b}$ metal release condition

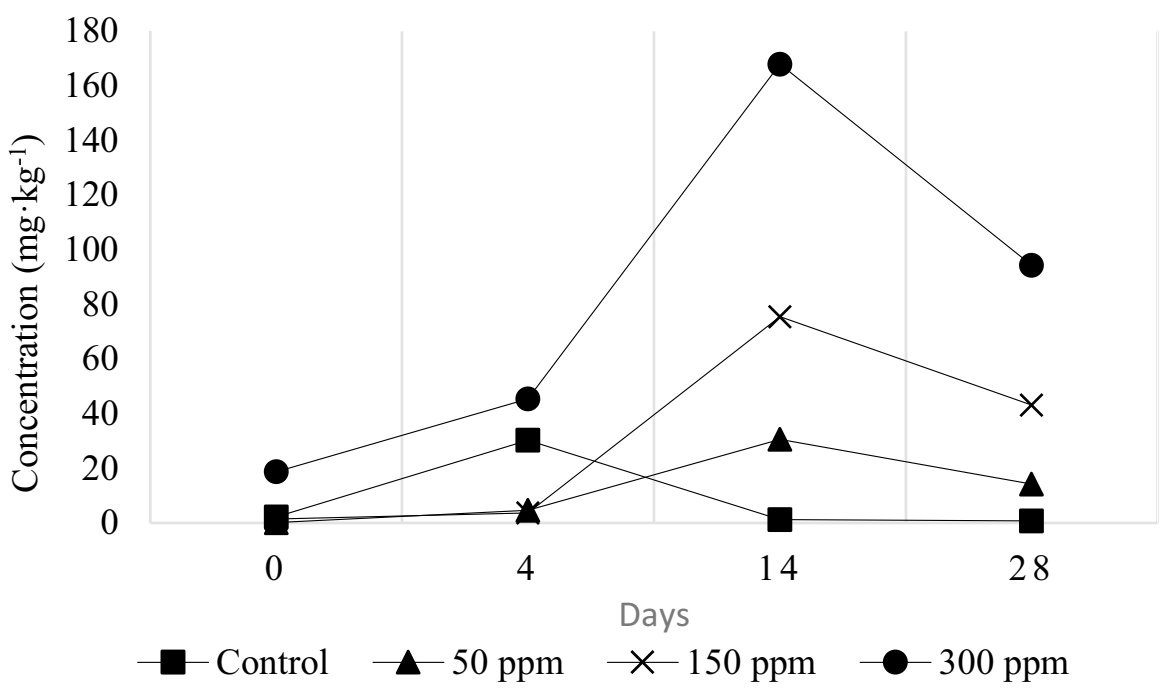

(a)

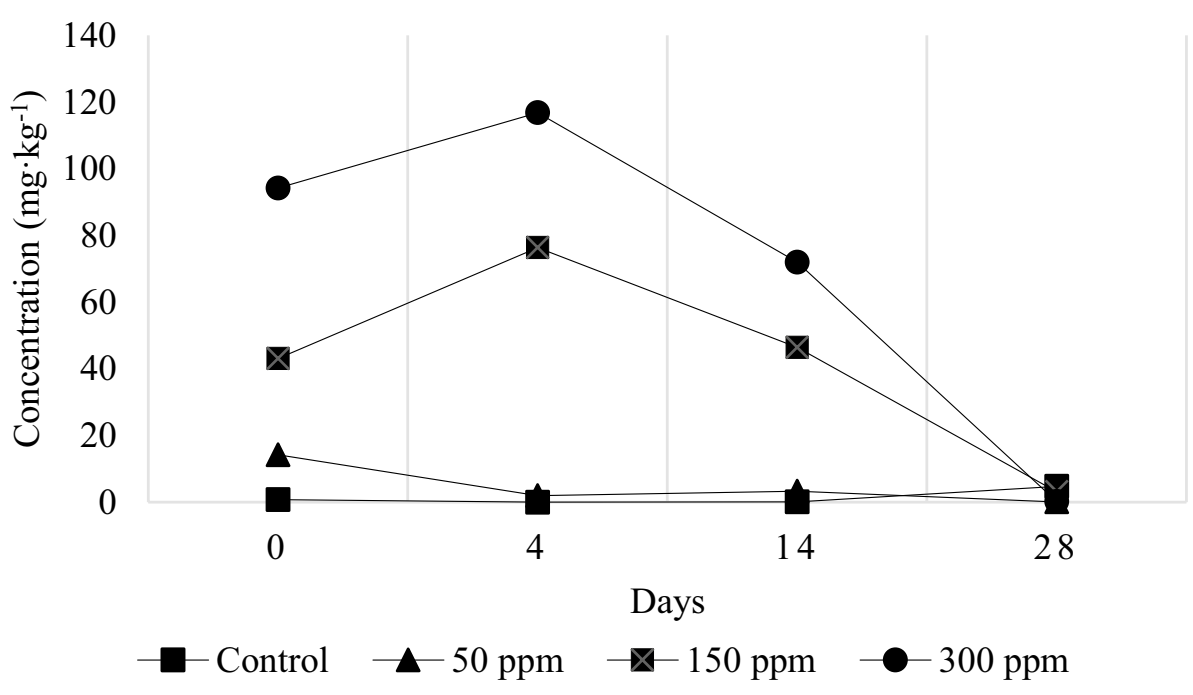

(b)

\subsection{Uptake rate and release rate}

The uptake and release rate of $\mathrm{Cr}$ and $\mathrm{Ni}$ in all treatments tended to fluctuate (Table 3). Cr uptake rate in all treatments tended to have a higher value when compared to its release rate, apart from $50 \mathrm{ppm}$ treated plants at days 4 and 28 and 300 ppm treated plants at day 28 . On the other hand, the Ni uptake rate was higher on some treatment $(150 \mathrm{ppm}$ at days 14 and 28 and 300 ppm at days 4, 14, and 28). Meanwhile, $50 \mathrm{ppm}$ Ni-treated plants reported a higher release rate except for day 28.

According to Chen et al. [3], uptake and release rates are affected by the availability of heavy metals in soil, plant metabolism, soil acidity, the presence of other metals, and the composition of soil organic matter. Soil pH that allows metal absorption to be carried out ranges from 3.9 to 5.7. Referring to this value, the soil $\mathrm{pH}$ in this study (Table 1) did not allow the metal absorption process to be optimum because the $\mathrm{pH}$ value is more alkaline, which was in the range of 6.8-7.

$\mathrm{Cr}$ uptake rate in this study demonstrated a higher value, while Ni uptake rate exhibited a lower value when compared to its release rate. High uptake rate in plants is proven to represent an essential trait as a phytoremediation agent $[3,17]$. In this context, $C$. zizanioides is proven to be useful as an alternative to phytoremediation in $\mathrm{Cr}$-contaminated areas. This finding is supported by the characteristics of $C$. zizanioides, which have a deep and extensive root penetration system, a good nutrient 
Fig. 4 Ni concentration in leaves $\left(\mathrm{mg} \mathrm{kg}^{-1}\right)$ a metal uptake condition and $\mathbf{b}$ metal release condition

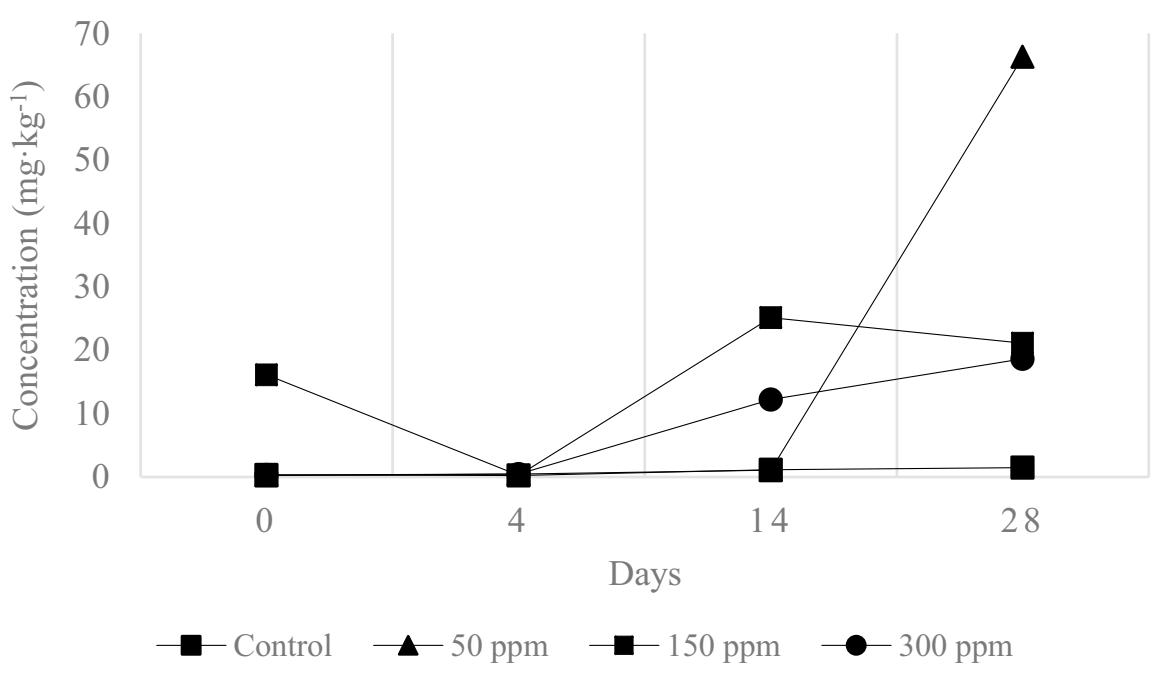

(a)

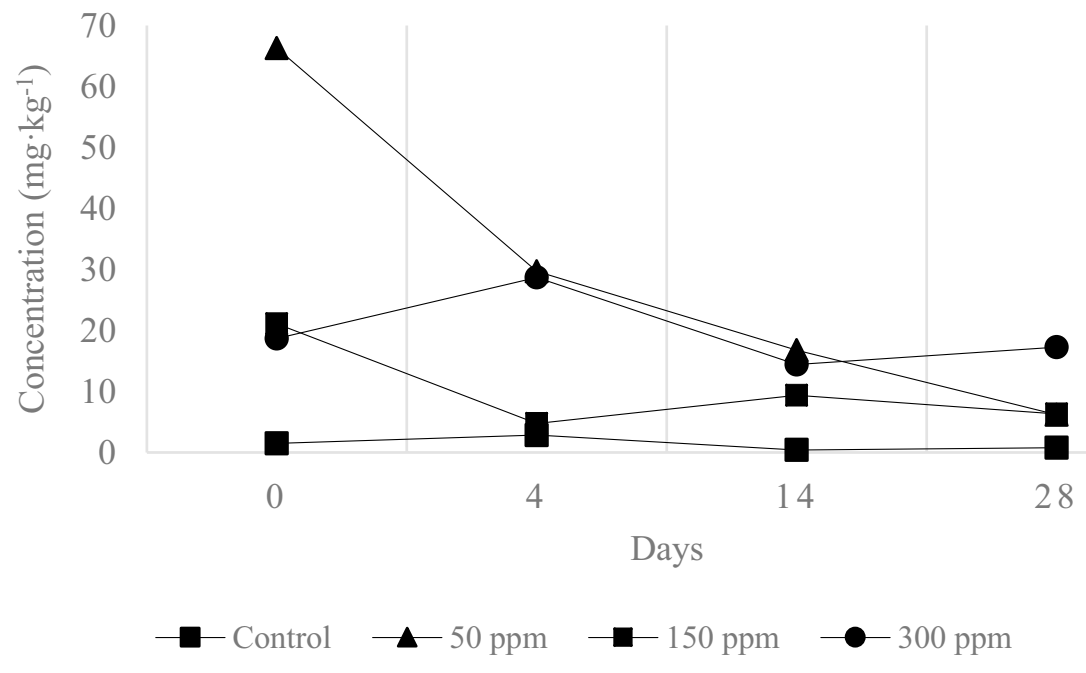

(b)
Table 3 Metal uptake rate and release rate in vetiver ( $C$. zizanioides)

\begin{tabular}{|c|c|c|c|c|c|}
\hline \multirow[t]{2}{*}{ Day } & \multirow{2}{*}{$\begin{array}{l}\text { Treatment } \\
(\mathrm{ppm})\end{array}$} & \multicolumn{2}{|l|}{$\mathrm{Cr}$} & \multicolumn{2}{|l|}{$\mathrm{Ni}$} \\
\hline & & $\begin{array}{l}\text { Uptake rate } \\
\left(\mathrm{mg} \mathrm{kg}^{-1} \mathrm{~d}^{-1}\right)\end{array}$ & $\begin{array}{l}\text { Release rate } \\
\left(\mathrm{mg} \mathrm{kg}^{-1} \mathrm{~d}^{-1}\right)\end{array}$ & $\begin{array}{l}\text { Uptake rate } \\
\left(\mathrm{mg} \mathrm{kg}^{-1} \mathrm{~d}^{-1}\right)\end{array}$ & $\begin{array}{l}\text { Release rate } \\
\left(\mathrm{mg} \mathrm{kg}^{-1} \mathrm{~d}^{-1}\right)\end{array}$ \\
\hline \multirow[t]{3}{*}{4} & 50 & -6.40 & 3.07 & 0.05 & 9.15 \\
\hline & 150 & -6.64 & -8.32 & 0.01 & 4.09 \\
\hline & 300 & 3.78 & -5.64 & 0.05 & -2.51 \\
\hline \multirow[t]{3}{*}{14} & 50 & 2.09 & 0.78 & -0.01 & 3.54 \\
\hline & 150 & 5.30 & -0.24 & 1.71 & 0.84 \\
\hline & 300 & 11.90 & 1.59 & 0.79 & 0.30 \\
\hline \multirow[t]{3}{*}{28} & 50 & 0.48 & 0.51 & 2.31 & 2.15 \\
\hline & 150 & 1.51 & 1.43 & 0.70 & 0.53 \\
\hline & 300 & 3.34 & 3.36 & 0.61 & 0.05 \\
\hline
\end{tabular}


absorption ability, and a high tolerance for environmental stress conditions [9].

\subsection{Phytoremediation potential of vetiver ( $C$. zizanioides)}

The use of $C$. zizanioides as a phytoremediation agent in this study can be evaluated by several indexes, such as bioconcentration factor (BCF), biological absorption coefficient (BAC), and translocation factor (TF) $[11,14,15,38]$. Bioconcentration factor (BCF) is an indicator of the translocation process of available metals from soil to plants. Biological absorption coefficient (BAC) is an indicator of accumulated levels of metals in plants. Translocation factor (TF) is an indicator of the translocation ability of metal from roots to shoot $[11,16]$. Plants used for phytoextraction generally have BCF and TF values $>1$ (Yoon et al. 2006). Plants used for phytostabilization have values of $B C F>1$ and TF $<1$ [14]. On the other hand, plants with BAC and TF values $>1$ have the potential to be hyperaccumulator plants [11]. According to Baker and Brooks (1989) in Yoon et al. [38], hyperaccumulator plants can accumulate $\mathrm{Cr}$ and $\mathrm{Ni}$ as much as $>1000 \mathrm{mg} \mathrm{kg}^{-1}$.

All Cr-treated plants at the uptake period showed a significant difference in $\mathrm{Cr}$ accumulation in leaves and roots. At the release period, only $\mathrm{Cr}$ accumulation in roots showed significant differences. All Ni-treated plants showed a significant difference in the accumulation in the roots and only the $300 \mathrm{ppm}$ treated plants showed a significant difference in the accumulation in the leaves. Only the $300 \mathrm{ppm}$ treated plants at the release period showed to be significantly different in the leaves. Plants given $\mathrm{Cr}$ treatment showed that $\mathrm{Cr}$ was largely accumulated in the roots, except for $150 \mathrm{ppm}$ and $300 \mathrm{ppm}$ at the uptake period. In contrast, plants given Ni treatment showed that $\mathrm{Ni}$ was largely accumulated in the leaves. This indicates that $\mathrm{Cr}$ is generally retained in the roots, while $\mathrm{Ni}$ is effectively translocated into the aerial part of the plants. Similar findings indicated that heavy metal content was highly accumulated in the vetiver roots. Generally, metal uptake was higher in vetiver root than in the shoot due to the plant root structure that can form a high surface area and due to restricted heavy metal translocation from root to shoot [31]. High Ni accumulation in the aerial part of the plants indicated a high translocation ability. Previous studies [31] also reported that essential elements ( $M n$ and $\mathrm{Zn}$ ) were largely accumulated in the shoot than root due to restricted accumulation in the roots for some metal elements required for plant growth.

In this study, only BCF value at uptake period from $300 \mathrm{ppm} \mathrm{Cr}$ was $>1$, while other treatments were $<1$. Only BAC value from $50 \mathrm{ppm} \mathrm{Ni}$ was $>1$. TF values from 150 ppm Cr, 300 ppm Cr, 50 ppm Ni, and 150 ppm Ni were $>1$ (Tables 4,5$)$. Previous studies reported BCF, BAC,
Table 4 Cr concentration in soil, leaves, and root in vetiver (C. zizanioides) with BCF, BAC, and TF values

\begin{tabular}{|c|c|c|c|c|c|c|}
\hline Period & Soil $\left(\mathrm{mg} \mathrm{kg}^{-1}\right)$ & Leaves $\left(\mathrm{mg} \mathrm{kg}^{-1}\right)$ & $\operatorname{Root}\left(\mathrm{mg} \mathrm{kg}^{-1}\right)$ & $\mathrm{BCF}$ & BAC & TF \\
\hline \multicolumn{7}{|l|}{50 ppm } \\
\hline \multicolumn{7}{|l|}{ Uptake } \\
\hline Control & 0.00 & $0.76^{*} \pm 0.82$ & $0.33^{*} \pm 0.57$ & 0.53 & 0.50 & 0.94 \\
\hline Treated & 28.14 & $14.20^{*} \pm 2.77$ & $15.05^{*} \pm 0.00$ & & & \\
\hline \multicolumn{7}{|l|}{ Release } \\
\hline Control & 3.84 & $4.72 \pm 5.11$ & $0.11 \pm 0.19$ & 0.04 & 0.01 & 0.24 \\
\hline Treated & 4.92 & $0.05 \pm 0.01$ & $0.22 \pm 0.38$ & & & \\
\hline \multicolumn{7}{|l|}{150 ppm } \\
\hline \multicolumn{7}{|l|}{ Uptake } \\
\hline Control & 0.00 & $0.76^{*} \pm 0.82$ & $0.33^{*} \pm 0.57$ & 0.39 & 0.46 & 1.20 \\
\hline Treated & 92.73 & $43.04^{*} \pm 1.54$ & $35.96^{*} \pm 0.33$ & & & \\
\hline \multicolumn{7}{|l|}{ Release } \\
\hline Control & 3.85 & $4.72 \pm 5.11$ & $0.11 * \pm 0.19$ & 0.75 & 0.48 & 0.63 \\
\hline Treated & 6.53 & $3.11 \pm 0.87$ & $4.90^{*} \pm 0.98$ & & & \\
\hline \multicolumn{7}{|l|}{300 ppm } \\
\hline \multicolumn{7}{|l|}{ Uptake } \\
\hline Control & 0.00 & $0.76^{*} \pm 0.82$ & $0.33^{*} \pm 0.57$ & 0.06 & 0.45 & 7.71 \\
\hline Treated & 209.50 & $94.22 * \pm 1.85$ & $12.21^{*} \pm 0.19$ & & & \\
\hline \multicolumn{7}{|l|}{ Release } \\
\hline Control & 3.84 & $4.72 \pm 5.11$ & $0.11^{*} \pm 0.19$ & 2.89 & 0.04 & 0.01 \\
\hline Treated & 5.21 & $0.19 \pm 0.00$ & $15.04^{*} \pm 0.57$ & & & \\
\hline
\end{tabular}

*Indicating a statistically significance different $(p<0.05)$ 
Table 5 Ni concentration in soil, leaves, and root in vetiver (C. zizanioides) with BCF, BAC, and TF values

\begin{tabular}{|c|c|c|c|c|c|c|}
\hline Period & Soil $\left(\mathrm{mg} \mathrm{kg}^{-1}\right)$ & Leaves $\left(\mathrm{mg} \mathrm{kg}^{-1}\right) \mathrm{r}$ & $\operatorname{Root}\left(\mathrm{mg} \mathrm{kg}^{-1}\right)$ & BCF & BAC & TF \\
\hline \multicolumn{7}{|l|}{50 ppm } \\
\hline \multicolumn{7}{|l|}{ Uptake } \\
\hline Control & 4.61 & $1.48 \pm 1.33$ & $1.19^{*} \pm 1.14$ & 0.17 & 1.84 & 10.78 \\
\hline Treated & 35.98 & $66.29 \pm 0.76$ & $6.15^{*} \pm 0.63$ & & & \\
\hline \multicolumn{7}{|l|}{ Release } \\
\hline Control & 8.55 & $0.79 \pm 0.71$ & $0.85 \pm 1.25$ & 0.05 & 0.27 & 5.63 \\
\hline Treated & 23.05 & $6.19 \pm 0.07$ & $1.10 \pm 0.96$ & & & \\
\hline \multicolumn{7}{|l|}{150 ppm } \\
\hline \multicolumn{7}{|l|}{ Uptake } \\
\hline Control & 4.61 & $1.48 \pm 1.33$ & $1.19^{*} \pm 1.14$ & 0.03 & 0.13 & 4.17 \\
\hline Treated & 156.37 & $21.10 \pm 2.22$ & $5.06^{*} \pm 1.40$ & & & \\
\hline \multicolumn{7}{|l|}{ Release } \\
\hline Control & 8.55 & $0.79 \pm 0.71$ & $0.85 \pm 1.25$ & 0.09 & 0.80 & 8.46 \\
\hline Treated & 7.95 & $6.35 \pm 0.67$ & $0.75 \pm 0.66$ & & & \\
\hline \multicolumn{7}{|l|}{300 ppm } \\
\hline \multicolumn{7}{|l|}{ Uptake } \\
\hline Control & 4.61 & $1.48^{*} \pm 1.33$ & $1.19^{*} \pm 1.14$ & 0.08 & 0.07 & 0.92 \\
\hline Treated & 257.94 & $18.65^{*} \pm 2.80$ & $20.37^{*} \pm 0.87$ & & & \\
\hline \multicolumn{7}{|l|}{ Release } \\
\hline Control & 8.55 & $0.79 * \pm 0.71$ & $0.85 \pm 1.25$ & 0.18 & 1.61 & 8.90 \\
\hline Treated & 10.70 & $17.28^{*} \pm 2.59$ & $1.94 \pm 1.39$ & & & \\
\hline
\end{tabular}

*Indicating a statistically significance different $(p<0.05)$ and TF values of $\mathrm{Cr}$ for $\mathrm{C}$. zizanioides grown on minesoil were $0.95,0.79$, and 0.83 , respectively. On the other hand, BCF, BAC, and TF values of Ni were $0.93,0.43$, and 0.46 , respectively. The data indicated that $\mathrm{Cr}$ and $\mathrm{Ni}$ accumulated by plants were largely retained in the roots [2]. When compared to findings in this study, it showed a higher result in some treatments, which indicated an effective heavy metal translocation from root to shoot by plants, as shown by general TF values $>1$. BCF and BAC reveal efficient uptake of heavy metals by root and shoot. A higher BCF value indicates that the root parts of the plants accumulated higher heavy metal concentration than the shoot parts. In addition, BAC values reported by Tariq et al. [34] for C. zizanioides were 0.31 and 0.26 for $\mathrm{Cr}$. Findings in this study showed a similar result to the previous studies, which were $<1$. Plants treated with $50 \mathrm{ppm}$ $\mathrm{Cr}$ at the uptake period showed a high $\mathrm{Cr}$ accumulation supported by its high $\mathrm{Cr}$ absorption ability (55.9\%) (Table 2). Plants treated with $\mathrm{Cr}$ in this study could not be categorized as hyperaccumulators due to accumulation by plants that only attained up to $167.8 \mathrm{mg} \mathrm{kg}^{-1}$. C. zizanioides treated with 50 ppm $\mathrm{Cr}$ showed a high $\mathrm{Cr}$ accumulation ability supported by its high $\mathrm{Cr}$ absorption ability (55.9\%) (Table 2). Plants treated with 50 ppm Ni showed a hyperaccumulator ability seen from BAC and TF values $>1$. However, plants could only accumulate up to $66.3 \mathrm{mg} \mathrm{kg}^{-1}$ of $\mathrm{Ni}$, which was far below the criteria for hyperaccumulator species, so plants could not be categorized as hyperaccumulators.

At the release period, only BCF values from 300 ppm $\mathrm{Cr}$ were $>1$. Only BAC values from 300 ppm Ni showed to be $>1$. In addition, TF values from all Ni-treated plants were $>1$ (Tables 4 and 5). When compared to previous findings [2], the recent findings showed a higher $B C F$, $\mathrm{BAC}$, and TF values in some treatments. Plants treated with 300 ppm Ni showed a potential hyperaccumulator ability as supported by its BAC and TF values $>1$. However, accumulation in plant parts had not yet reached the criteria for hyperaccumulator species, which only accumulate up to $28.7 \mathrm{mg} \mathrm{kg}^{-1}$, so plants still could not be categorized as hyperaccumulator species. Nonetheless, $C$. zizanioides indicated a high translocation of $\mathrm{Ni}$ when given 50 ppm and 150 ppm treatments at uptake period and 300 ppm at release period, as shown by TF values $>1$.

According to Maiti (2003) in Ramachandra et al. [26], the normal concentration of $\mathrm{Cr}$ in plants ranges from 0.03 to $14 \mathrm{mg} \mathrm{kg}^{-1}$, while the critical concentration range is $5-30 \mathrm{mg} \mathrm{kg}^{-1}$. The normal concentration of $\mathrm{Ni}$ in plants ranges from 0.02 to $5 \mathrm{mg} \mathrm{kg}^{-1}$, while the critical concentration ranges from 10 to $100 \mathrm{mg} \mathrm{kg}^{-1}$. When compared with the recent findings, all treated plants accumulated higher $\mathrm{Cr}$ and $\mathrm{Ni}$ concentration than their normal concentrations. This indicates that C. zizanioides treated with various concentrations of $\mathrm{Cr}$ and $\mathrm{Ni}$ demonstrated the ability 
to tolerate these metals (heavy metal-tolerant species) but did not reach the hyperaccumulator concentration. Research conducted by Patandungan et al. [23] on Cdcontaminated soil reported the ability of $C$. zizanioides to accumulate $\mathrm{Cd}$, which also could not be categorized as a hyperaccumulator plant because it could only accumulate up to $0.298 \mathrm{mg} \mathrm{kg}^{-1}$.

Rice (Oryza sativa) comes from the same family as vetiver, so its ability to absorb, accumulate, and translocate heavy metals can be used as a comparison. Based on previous studies, it is reported that most heavy metal accumulation by rice is found in roots, followed by stems, then grains. The accumulation of $\mathrm{Cr}$ and $\mathrm{Ni}$ due to excessive metal absorption in the soil causes the concentration of these two metals to increase in rice grains. Although the accumulation is not as high as in the roots, the presence of $\mathrm{Cr}$ and $\mathrm{Ni}$ in rice grains is a potential threat to human health $[7,8,27,32]$.

From the experiment, it could not be concluded whether $C$. zizanioides can be used for phytoextraction or phytostabilization. This may be due to the uneven distribution of heavy metals in the soil, so that absorption by plants has not occurred optimally and only some of the heavy metals available can be absorbed and accumulated by the plant roots. This may also cause the concentration of $\mathrm{Cr}$ in the soil at $300 \mathrm{ppm}$ treatment and the concentration of $\mathrm{Ni}$ in the soil at $150 \mathrm{ppm}$ and $300 \mathrm{ppm}$ treatments to increase after 28 days of exposure to heavy metal wastewater. This statement is also supported by the research conducted by Patandungan et al. and Ambarwati and Bahri $[1,23]$ who stated that $C$. zizanioides demonstrate great potential in processing heavy metal wastewater so that further research is needed. Research by Danh et al. [6] also showed that vetiver was able to accumulate heavy metals in higher amounts than other plants. To overcome this problem, research can be carried out in a longer time, so the results obtained can represent the ability of vetiver to both absorb and release heavy metals maximally.

\section{Conclusion}

Chrysopogon zizanioides was found effective in removing heavy metals $(\mathrm{Cr}$ and $\mathrm{Ni})$ depending on the concentration of heavy metals, which affect the uptake rate, release rate, and metal accumulation in plant parts. Plants treated with a high concentration of heavy metals showed a decrease in absorption ability due to metal saturation in plants. Plants treated with $\mathrm{Cr}$ showed a high uptake rate when compared to its release rate, while plants treated with Ni showed a low uptake and release rate. $\mathrm{A}$ high $\mathrm{Cr}$ uptake rate indicates that $\mathrm{C}$. zizanioides can be potentially used as a phytoremediation agent supported by its characteristics, i.e., deep and extensive root penetration system, good nutrient absorption ability, and high tolerance for environmental stress conditions. The uptake and release rate of $C$. zizanioides in this study tend to fluctuate because of the varying concentrations given, which affecting the bioavailability of heavy metals in the soil. Low solubility and mobility of $\mathrm{Cr}$ and $\mathrm{Ni}$ in soil due to low soil acidity also affect metal uptake and release rate. The accumulated metals in plant parts showed a different result for $\mathrm{Cr}$ and $\mathrm{Ni}$. $\mathrm{Cr}$ was largely accumulated in the roots, while $\mathrm{Ni}$ was largely accumulated in the leaves. This indicates that $\mathrm{Cr}$ is retained in the roots, while $\mathrm{Ni}$ is effectively translocated into aerial plant parts. The evaluated values of $B C F$, $B A C$, and TF in this study only showed several treatments to be $>1$. None of the treatments during 28-day uptake and 28-day release periods demonstrated the potential to be used for phytoextraction, phytostabilization, or as a hyperaccumulator species. Nevertheless, findings from this study have demonstrated the potential use of C. zizanioides as heavy metal-tolerant species due to its ability to accumulate higher $\mathrm{Cr}$ and $\mathrm{Ni}$ concentrations above their normal concentration range. C. zizanioides also presented the potential as an alternative species for phytoremediation at least in lightly polluted areas.

Acknowledgements Authors would like to thank Research Unit for Clean Technology, Indonesian Institute of Sciences (LIPI), Bandung, for the research facilities and Faculty of Biology, Universitas Gadjah Mada for the help and the cooperation.

Author contributions All authors contributed to the study conception and design. Material preparation, data collection, and analysis were performed by Yuanita Sekar Chintani. Verification of the overall replication/reproducibility of results/experiments and other research outputs were performed by Erni Saurmalinda Butar Butar and Tarzan Sembiring. Supervision was performed by Tarzan Sembiring and Andhika Puspito Nugroho. The first draft of the manuscript was written by Yuanita Sekar Chintani, and all authors commented on previous versions of the manuscript. All authors read and approved the final manuscript.

Funding This study was funded by Indonesian Institute of Sciences (LIPI), Bandung.

Availability of data and materials The datasets used and/or analyzed during the current study are available from the corresponding author on reasonable request.

\section{Compliance with ethical standards}

Ethics approval and consent to participate Not applicable.

Consent for publication Not applicable.

Competing interests The authors declare that they have no competing interests. 
Open Access This article is licensed under a Creative Commons Attribution 4.0 International License, which permits use, sharing, adaptation, distribution and reproduction in any medium or format, as long as you give appropriate credit to the original author(s) and the source, provide a link to the Creative Commons licence, and indicate if changes were made. The images or other third party material in this article are included in the article's Creative Commons licence, unless indicated otherwise in a credit line to the material. If material is not included in the article's Creative Commons licence and your intended use is not permitted by statutory regulation or exceeds the permitted use, you will need to obtain permission directly from the copyright holder. To view a copy of this licence, visit http://creativecommons .org/licenses/by/4.0/.

\section{References}

1. Ambarwati Y, Bahri S (2018) Review: phytoremediation of heavy metal wastewater with vetiver. Analit Anal Environ Chem 3:139-147. https://doi.org/10.23960/aec.v3.i2.2018.p139-147 (in Indonesian)

2. Banerjee R, Goswami P, Pathak K, Mukherjee A (2016) Vetiver grass: an environment clean-up tool for heavy metal contaminated iron ore mine-soil. Ecol Eng 90:25-34. https://doi. org/10.1016/j.ecoleng.2016.01.027

3. Chen C, Huang D, Liu J (2009) Functions and toxicity of nickel in plants: recent advances and future prospects. Clean 37:304-313. https://doi.org/10.1002/clen.200800199

4. DalCorso GE, Fasani E, Manara A, Visioli G, Furini A (2019) Heavy metal pollutions: state of the art and innovation in phytoremediation. Int J Mol Sci 20:3412. https://doi.org/10.3390/ijms2 0143412

5. Danh LT, Truong P, Mammucari R, Pu Y, Foster N (2012) Phytoremediation of soils contaminated by heavy metals, metalloids and radioactive materials using vetiver grass, Chrysopogon zizanioides. Phytotechnol Remed Environ Contam. https://doi. org/10.1201/b12954-16

6. Danh LT, Truong P, Mammucari R, Tran T, Foster N (2009) Vetiver grass, Vetiveria zizanioides: a choice plant for phytoremediation of heavy metals and organic wastes. Int J Phytoremediation 11:664-691. https://doi.org/10.1080/15226510902787302

7. Halim MA, Majumder RK, Zaman MN (2014) Paddy soil heavy metal contamination and uptake in rice plants from the adjacent area of Barapukuria Coal Mine, Northwest Bangladesh. Arab J Geosci 8:3391-3401. https://doi.org/10.1007/s1251 7-014-1480-1

8. Hseu ZY, Lai YJ (2017) Nickel accumulation in paddy rice on serpentine soils containing high geogenic nickel contents in Taiwan. Environ Geochem Health. https://doi.org/10.1007/s1065 3-017-9925-6

9. Komarawidjaja W, Garno YS (2015) The role of vetiver grass (Chrysopogon zizanioides) in the phytoremediation of river water pollution. Jurnal Teknologi Lingkungan 17:7-14. https:// doi.org/10.29122/jtl.v17i1.1459 (in Indonesian)

10. Kristianto $S$, Wilujeng $S$, Wahyudiarto $D$ (2017) Analysis of heavy metal chromium $(\mathrm{Cr})$ in Kali Pelayaran as a form of efforts to prevent environmental pollution in Sidoarjo region. Jurnal Biota 3:66-70. https://doi.org/10.19109/Biota.v3i2.1196 (in Indonesian)

11. Li M, Luo Y, Su Z (2007) Heavy metal concentrations in soils and plant accumulation in restored manganese mineland in Guangxi, South China. Environ Pollut 147:168-175. https://doi. org/10.1016/j.envpol.2006.08.006

12. Liphadzi MS, Kirkham MB, Musil CF (2005) Phytoremediation of soil contaminated with heavy metals: a technology for rehabilitation of the environment. S Afr J Bot 71(1):24-37. https ://doi.org/10.1016/S0254-6299(15)30145-9

13. Loney R (2010) Units and unit conversion guide. Environmental and Resource Studies Program, Trent University

14. Lorestani B, Yousefi N, Cheraghi M, Farmany A (2013) Phytoextraction and phytostabilization potential of plants grown in the vicinity of heavy metal-contaminated soils: a case study at an industrial town site. Environ Monit Assess 185:10217-10223. https://doi.org/10.1007/s10661-013-3326-9

15. Malik R, Husain S, Nazir I (2010) Heavy metal contamination and accumulation in soil and wild plant species from industrial area of Islamabad, Pakistan. Pak J Bot 42:291-301

16. Mu J, Hu Z, Huang L, Tang S, Holm PE (2018) Influence of alkaline silicon-based amendment and incorporated with biochar on the growth and heavy metal translocation and accumulation of vetiver grass (Vetiveria zizanioides) grown in multi-metalcontaminated soils. J Soils Sedim 19:2277-2289. https://doi. org/10.1007/s11368-018-2219-5

17. Nouri J, Khorasani N, Lorestani B, Karami M, Hassani A, Yousefi $\mathrm{N}$ (2009) Accumulation of heavy metals in soil and uptake by plant species with phytoremediation potential. Environ Earth Sci 59:315-323. https://doi.org/10.1007/s12665-009-0028-2

18. Nurhasni N, Salimin Z, Nurilfitriyani I (2013) Electroplating industrial wastewater treatment with flocculation coagulation process. Valensi 3:41-47. https://doi.org/10.15408/jkv.v3i1.328 (in Indonesian)

19. Oktavia Z, Budiyono DNAY (2016) The effect of phytoremediation exposure length variations of Kiambang (Salvinia molesta) on cadmium $(\mathrm{Cd})$ concentrations in home industry batik " $\mathrm{X}$ " wastewater in Magelang. Jurnal Kesehatan Masyarakat 4:238245 (in Indonesian)

20. Oshunsanya SO, Aliku O (2017) Vetiver grass: a tool for sustainable agriculture. https://doi.org/10.5772/intechopen.69303

21. Panda SK, Choudury S (2005) Chromium stress in plants. Braz J Plant Physiol 17:95-102. https://doi.org/10.1590/S1677-04202 005000100008

22. Pandia S, Warman B (2016) Use of Jengkol skin as an adsorbent in the absorption of $\mathrm{Cd}$ (II) in metal coating industry wastewater. Jurnal Teknik Kimia USU 5:57-63 ((in Indonesian))

23. Patandungan A, Syamsidar HS, Aisyah, (2016) Phytoremediation of vetiver (Vetiver zizanioides) against cadmium (Cd)-contaminated soil in TPA Tamangapa Antang Makassar. Al-Kimia 4:8-21. https://doi.org/10.24252/al-kimia.v4i2.1676 (in Indonesian)

24. Pequerul A, Perez C, Madero P, Val J, Monge E (1993) A rapid wet digestion method for plant analysis. Dev Plant Soil Sci 53:3-6. https://doi.org/10.1007/978-94-017-2496-8_1

25. Phusantisampan T, Meeinkuirt W, Saengwilai P, Pichtel J, Chaiyarat R (2016) Phytostabilization potential of two ecotypes of Vetiveria zizanioides in cadmium-contaminated soils: greenhouse and field experiments. Environ Sci Pollut Res. https://doi. org/10.1007/s11356-016-7229-5

26. Ramachandra TV, Sudarshan PB, Mahesh MK, Vinay S (2017) Spatial patterns of heavy metal accumulation in sediments and macrophytes of Bellandur wetland, Bangalore. J Environ Manag 206:1204-1210. https://doi.org/10.1016/j.jenvman.2017.10.014

27. Satpathy D, Reddy MV, Dhal SP (2014) Risk assessment of heavy metals contamination in paddy soil, plants, and grains (Oryza sativa L.) at the east coast of India. BioMed Res Int. https://doi. org/10.1155/2014/545473

28. Shahandeh H, Hossner LR (2000) Plant screening for chromium phytoremediation. Int J Phytoremed 2:31-51. https://doi. org/10.1080/15226510008500029

29. Shanker AK, Cervantes C, Loza-Tavera H, Avudainayagam S (2005) Chromium toxicity in plants. Environ Int 31:739-753. https://doi.org/10.1016/j.envint.2005.02.003 
30. Singh HP, Mahajan P, Kaur S, Batish DR, Kohli RK (2013) Chromium toxicity and tolerance in plants. Environ Chem Lett 11:229-254. https://doi.org/10.1007/s10311-013-0407-5

31. Suelee AL, Hasan SNMS, Kusin FD, Yusuff FM, Ibrahim ZZ (2017) Phytoremediation potential of vetiver grass (Vetiveria zizanioides) for treatment of metal-contaminated water. Water Air Soil Pollut 228:158. https://doi.org/10.1007/s11270-017-3349-x

32. Sundaramoorthy $P$, Chidambaram $A$, Ganesh KS, Unnikannan $P$, Baskaran L (2010) Chromium stress in paddy: (i) nutrient status of paddy under chromium stress; (ii) phytoremediation of chromium by aquatic and terrestrial weeds. C R Biol 333:597-607. https://doi.org/10.1016/j.crvi.2010.03.002

33. Tambunan JAM (2017) Phytoremediation of batik wastewater using vetiver (Chrysopogon zizanioides L.). Thesis, Institut Pertanian Bogor. https://repository.ipb.ac.id/handle/12345 6789/91354 (in Indonesian)

34. Tariq FS, Samsuri AW, Karam DS, Aris AZ (2016) Phytoremediation of gold mine tailings amended with iron-coated and uncoated rice husk ash by vetiver grass (Vetiveria zizanioides (Linn.) Nash). Appl Environ Soil Sci. https://doi.org/10.1155/2016/4151898
35. Truong P (1999) Vetiver grass for mine rehabilitation. PRVN, Bangkok

36. Turek A, Wieczorek K, Wolf WM (2019) Digestion procedure and determination of heavy metals in sewage sludge - an analytical problem. Sustainability 11:1753. https://doi.org/10.3390/su110 61753

37. Yap C, Ismail A, Tan S, Omar H (2003) Accumulation, depuration, and distribution of cadmium and zinc in the green-lipped mussel Perna viridis (Linnaeus) under laboratory conditions. Hydrobiologia 498:151-160. https://doi.org/10.1023/A:1026221930 811

38. Yoon J, Cao X, Zhou Q, Ma L (2006) Accumulation of Pb, Cu, and $\mathrm{Zn}$ in native plants growing on contaminated Florida site. Sci Tot Environ 368:456-464. https://doi.org/10.1016/j.scito tenv.2006.01.016

Publisher's Note Springer Nature remains neutral with regard to jurisdictional claims in published maps and institutional affiliations. 